\title{
Kontribusi dukungan keluarga terhadap motivasi belajar anak broken home
}

\author{
Linda Fitria $^{\left.1^{*}\right)}$, Mufadhal Barseli ${ }^{2}$ \\ ${ }^{12}$ Universitas Putra Indonesia YPTK Padang
}

\begin{tabular}{l} 
Article Info \\
\hline Article history: \\
Received Nov $13^{\text {th }}, 2020$ \\
Revised Des $17^{\text {th }}, 2020$ \\
Accepted Jan $11^{\text {th }}, 2021$ \\
\hline
\end{tabular}

\section{Keyword:}

Dukungan keluarga

Motivasi belajar

Broken home

\begin{abstract}
This study aims to determine the contribution of family support to the learning motivation of broken home children in grade X even semester SMK Negeri 9 Padang Academic Year 2019/2020. The population of this study was 418 people who were taken using 2019/2020, with a sample of 56 people who were taken using purposive sampling technique. The method used in this research is correlational quantitative descriptive. The data collection instrument used in this study was a questionnaire with a Likert scale model. Data analyzes were performed using statistical programs on the IBM Statistical 20 computer and Microsoft Excel. Based on the results of the study, data shows that there is a contribution of family support to the learning motivation of broken home children
\end{abstract}

\section{Corresponding Author:}

Linda Fitria,

Universitas Putra Indonesia YPTK Padang

Email: linda.fitria81@gmail.com

\section{Pendahuluan}

Pendidikan bertujuan untuk mengembangkan dan mengoptimalkan segala aspek yang ada dalam diri peserta didik baik dalam bidang akademik, sosial, agama, minat dan bakat melalui pendidikan formal berupa kegiatan pembelajaran, bimbingan dan latihan. Dalam mencapai tujuan tersebut, salah satu faktor yang mempengaruhinya adalah motivasi belajar. Motivasi belajar pada dasarnya membantu peserta didik dalam memahami dan menjelaskan bagaimana perilaku individu dalam belajar (Saptono, 2016). Motivasi belajar merupakan dorongan internal dan eksternal pada peserta didik yang sedang belajar untuk mengadakan perubahan tingkah laku, pada umumnya dengan berberapa indikator atau unsur yang mendukung (Uno, 2006). Motivation is a condition that activates and sustains behavior toward a goal. People are motivated to develop competence and solve problems by rewards and punishments but often have intrinsic reasons for learning that may be more powerful (Boekaerts, 2002). Motivasi adalah suatu kondisi yang mengaktifkan dan menopang perilaku menuju suatu tujuan. Orang-orang termotivasi untuk mengembangkan kompetensi dan memecahkan masalah dengan penghargaan dan hukuman, untuk belajar lebih giat.

Dari penjelasan di atas dapat disimpulkan motivasi belajar adalah suatu dorongan dan kekuatan internal ataupun eksternal yang bertujuan untuk meningkatkan kondisi-kondisi tertentu untuk melakukan kegiatan belajar agar terdapatnya keterampilan pada peserta didik dalam melakukan sesuatu dalam proses pembelajaran. Salah satu faktor yang mempengaruhi motivasi belajar adalah dukungan keluarga (F. Safitri \& Yuniwati, 2019), (Listyowati, 2018). Dukungan keluarga adalah suatu yang diterima oleh setiap anggota keluarga (Siregar, 2018), (Sefrina, 2016). Lingkungan keluarga di bedakan menjadi lingkungan keluarga 
harmonis dan lingkungan keluarga yang tidak harmois atau broken home. Tan, Ismanto, dan Babakal (2013) menyatakan bahwa dukungan orangtua memiliki hubungan yang signifikan terhadap motivasi belajar siswa. Penelitian ini bertujuan untuk melihat kontribusi dukungan keluarga terhadap motivasi belajar anak broken home.

\section{Metode}

Metode yang digunakan dalam penelitian ini adalah metode deskriptif kuantitatif korelasional. penelitian ini melihat bagaimana kontribusi dukungan keluarga terhadap motivasi belajar anak broken home. Menurut (Sugiyono, 2010) penelitian kuantitatif adalah metode penelitian yang berlandaskan pada filsafat positivisme, digunakan untuk meneliti pada populasi atau sampel tertentu, teknik pengambilan sampel pada umumnya dilakukan secara random, pengumpulan data menggunakan instrumen penelitian, analisis dara bersifat kuantitatif/statistik, dengan tujuan untuk menguji hipotesis yang telah ditetapkan. Penelitian deskriftif adalah suatu penelitian yang mendeskripsikan sutau gejala, fakta, peristiwa atau kejadian yang sedang atau sudah terjadi (Soendari, 2012), (Suliyanto \& MM, 2017). Sedangkan Menurut Yusuf (2005:84) penelitian korelasional adalah suatu metode peneltian yanng melihat sebarapa besar hubungan santara satu hubungan dengan hubungan lain (Sugiyono, 2010), (Annisa, 2010). Penelitian kuantitatif deskriptif korelasional adalah penelitian yang menjelaskan hubungan dua variabel atau lebih yang bersifat kuantitatif (Silalahi \& Atif, 2015).

\section{Hasil dan Pembahasan}

Berdasarkan hasil penelitian diperoleh data korelasi antara dukungan keluarga terhadap motivasi belajar anak broken home pada tabel berikut:

Tabel 2. Korelasi antara dukungan keluarga terhadap motivasi belajar anak broken home

\begin{tabular}{llcc}
\hline & & Correlations & \\
\hline & & Dukugan Keluarga & $\begin{array}{c}\text { Motivasi belajar anak broken } \\
\text { home }\end{array}$ \\
\hline Dukugan keluarga & Pearson Correlation & 1 & $.496^{* *}$ \\
\cline { 2 - 4 } & Sig. (2-tailed) & 56 & .000 \\
\cline { 2 - 4 } & $N$ & $.496^{* *}$ & 56 \\
\hline $\begin{array}{l}\text { Motivasi belajar } \\
\text { anak broken home }\end{array}$ & Pearson Correlation & .000 & 56 \\
\cline { 2 - 4 } & Sig. (2-tailed) & 56 & \\
\cline { 2 - 4 } & $N$ & & 56 \\
\hline **. Correlation is significant at the 0.01 level (2-tailed).
\end{tabular}

Berdasarkan hasil di atas maka dapat diketahui kontribusi dukungan keluarga terhadap motivasi belajar sebagai berikut:

$$
\begin{aligned}
\mathrm{KP} & =r^{2} \times 100 \% \\
& =0,496^{2} \times 100 \% \\
& =0,246016 \mathrm{X} 100 \% \\
& =24,6016 \\
& =25 \%
\end{aligned}
$$

Sehingga dapat dilihat bahwa kontribusi dukungan keluarga terhadap motivasi belajar anak broken home sebesar 25\%. Kasifikasi tingkat kontribusi berdasarkan hasil penelitian dapat dilihat pada table 2:

Tabel 2. Kasifikasi tingkat kontribusi berdasarkan hasil penelitian

\begin{tabular}{cc}
\hline Persentase kontribusi & Tingkat kontribusi \\
\hline $\mathbf{0 1 0} \%$ & Sangat Rendah \\
\hline $\mathbf{1 0 , 0 1 \% - 2 0 \%}$ & Rendah \\
\hline $\mathbf{2 0 , 1 \% - 3 0 \%}$ & Sedang \\
\hline $\mathbf{3 0 , 0 1 \% - 4 0 \%}$ & Tinggi \\
\hline $\mathbf{5 0 \%}$ & Sangat Tnggi \\
\hline
\end{tabular}

Kontribusi dukungan keluarga terhadap motivasi belajar anak broken home berdasarkan hasil penelitian sebesar 25\%, apabila dirujuk dari table 2 maka tingkat kontribusinya termasuk pada kategori sedang. 
Penelitian ini sejalan dengan penelitian Saragi, M. P. D., Iswari, M., \& Mudjiran, M. (2016). dengan judul "Kontribusi Konsep Diri Dan Dukungan Orangtua Terhadap Motivasi Belajar Siswa Dan Implikasinya Dalam Pelayanan Bimbingan Dan Konseling, penelitian ini menyatakan bahwa terdapat kontribusi konsep diri terhadap motivasi belajar siswa sebesar $24,2 \%$, dan kontribusi dukungan orang tua terhadap motivasi belajar siswa sebesar $18,8 \%$, serta kontribusi konsep diri dan dukungan orang tua secara bersama terhadap motivasi belajar siswa sebesar 30,7\%.

Menurut Uno (2012:23) aspek-aspek yang mempengaruhi motivasi belajar adalah sebagai berikut: aspek intrisik (harsat, keinginan, dorongan dan harapan yang berasal dari diri peserta didik) dan aspek ekstrinsik (lingkungan yang kondusif, sosio-ekonomi dan adanya penghargaan). Salah satu aspek ekstrinsik yang merupakan lingkungan yang kondusif termasuk di dalamnya dukungan orangtua (Kasiono, 2017).

Dukungan orangtua memiliki hubungan yang signifikan terhadap motivasi belajar siswa (Tan, Ismanto, \& Babakal, 2013). Menurut (Jahja, 2011) bahwa dengan adanya dukungan keluarga dalam memberi dorongan semangat serta motivasi dapat membangun rasa percaya diri siswa, menumbuhkan semangat belajar yang tinggi, dan membuat siswa mau melakukan aktivitas belajar dengan baik dan terkontrol. Menurut (Sarafino \& Smith, 2011) bahwa dukungan orangtua sangat berpengaruh terhadap keberhasilan anaknya dalam belajar. Dengan demikian, dukungan orangtua merupakan salah satu faktor yang berkontribusi terhadap motivasi belajar siswa.

Faktor yang mempengaruhi motivasi belajar yaitu: (1) aspirasi atau cita-cita siswa, (2) kemampuan siswa, (3) kondisi siswa, (4) kondisi lingkungan siswa, (5) dukungan orangtua, dan (6) upaya guru membelajarkan siswa (dan Mudjiono, 2009), (Pujadi, 2007).

Motivasi belajar dipengaruhi juga oleh cita-cita dan aspirasi, kemampuan peserta didik, kondisi peserta didik, kondisi lingkungan belajar, unsur-unsur dinamis dalam pembelajaran, dan upaya pengajar dalam membelajarkan peserta didik (Suciati, 2001), (Emda, 2018), (Suardi, 2018).

Sesuai dengan pendapat Epstein keterlibatan orangtua dalam sekolah anak yaitu: (1) keluarga mempunyai kewajiban dasar untuk menyediakan keselamatan dan kesehatan bagi anak remaja mereka, (2) sekolah mempunyai kewajiban dasar untuk berkomunikasi dengan keluarga mengenai program sekolah dan perkembangan anak mereka, (3) keterlibatan orangtua di sekolah harus ditingkatkan, (4) keterlibatan orangtua dalam aktivitas belajar di rumah harus ditingkatkan, (5) orangtua harus lebih sering terlibat dalam pengambilan keputusan di sekolah, dan (6) kolaborasi dan kerjasama dengan organisasi di masyarakat harus ditingkatkan (Santrock, 2003).

Dukungan orangtua adalah interaksi yang dikembangkan oleh orangtua yang dicirikan oleh perawatan, kehangatan, persetujuan, dan berbagai perasaan positif orangtua terhadap anak (Ellis, Thomas, dan Rollins dalam Lestari, 2012). Menurut Johnson dan Johnson (dalam Tarmidi dan Rambe, 2010) dukungan sosial merupakan keberadaan orang lain yang dapat diandalkan untuk dimintai bantuan, dorongan dan penerimaan apabila individu mengalami kesulitan.

House dan Kahn (dalam Hidayati, 2011) menyebutkan bentuk-bentuk dukungan sosial orangtua, yaitu dukungan emosional berupa cinta dan kasih sayang, ungkapan empati, perlindungan, perhatian dan kepercayaan, keterbukaan serta kerelaan dalam memecahkan masalah seseorang. Kemudian dukungan instrumental berupa bantuan uang, kesempatan, dan modifikasi lingkungan (Zahara, 2012), (A. Safitri, 2018). Selain itu, ada dukungan informasi berupa pemberian nasehat, arahan, dan pertimbangan tentang bagaimana seseorang harus berbuat. Serta dukungan penilaian berupa pemberian penghargaan atas usaha yang telah dilakukan, memberikan umpan balik, dan mengenai hasil atau prestasi yang diambil individu.

\section{Simpulan}

Berdasarkan hasil penelitian dapat disimpulkan bahwa dukungan keluarga berkontribusi terhadap motivasi belajar anak broken home. kontribusi dukugan keluarga terhadap motivasi belajar anak broken home berdasarkan penelitian ini sebesar $25 \%$. Sedangkan $75 \%$ lagi faktor yang berkontribusi terhadap motivasi belajar anak broken home seperti kontrol diri, konsep diri, pola asuh orang tua, fasilitas belajar, dukungan sosial dan lainlain.

\section{References}

Annisa, W. (2010). Metode Penelitian Korelasional.

Boekaerts, M. (2002). Motivation to learn: International Academy of Education Brussels, Belgium. 
dan Mudjiono, D. (2009). Teaching and learning: Jakarta: Rineka Cipta.

Emda, A. (2018). Kedudukan motivasi belajar siswa dalam pembelajaran. Lantanida Journal, 5(2), 172-182.

Jahja, Y. (2011). Psikologi perkembangan: Kencana.

Kasiono, R. I. Y. (2017). Pengaruh Dukungan Orang Tua Dan Motivasi Belajar Terhadap Hasil Belajar Siswa Kelas X Pada Mata Pelajaran Ekonomi Di Sma Negeri 8 Kota Jambi. SJEE: Scientific Journals of Economic Education, 1(1), 129-144.

Listyowati, N. (2018). Dukungan Orang Tua Dan Fasilitas Belajar Terhadap Motivasi Belajar dan Dampaknya Pada Hasil Belajar Matematika Siswa SMP. Fakultas Keguruan dan Ilmu Pendidikan. Universitas Muhamadiya Surakarta.

Pujadi, A. (2007). Faktor-faktor yang mempengaruhi motivasi belajar mahasiswa: studi kasus pada fakultas ekonomi universitas bunda mulia. Business Management Journal, 3(2).

Safitri, A. (2018). Hubungan dukungan sosial orang tua terhadap prokrastinasi akademik dalam menyelesaikan skripsi. Insight: Jurnal Pemikiran dan Penelitian Psikologi, 14(2), 154-173.

Safitri, F., \& Yuniwati, C. (2019). Pengaruh Motivasi dan Dukungan Keluarga terhadap Prestasi Belajar Mahasiswa Tingkat II Prodi D-III Kebidanan Universitas Ubudiyah Indonesia. Journal of Healthcare Technology and Medicine, 2(2), 154-161.

Santrock, J. W. (2003). Adolescence perkembangan remaja (terjemahan). Jakarta: Erlangga.

Saptono, Y. J. (2016). Motivasi dan keberhasilan belajar siswa. REGULA FIDEI: Jurnal Pendidikan Agama Kristen, 1(1), 181-204.

Sarafino, E., \& Smith, T. (2011). Health Psychology Biopsychosocial Interactions Edisi 7: New York: Jhon Willey \& Sons, Inc.

Sefrina, F. (2016). Hubungan Dukungan Keluarga dan Keberfungsian Sosial pada Pasien Skizofrenia Rawat Jalan. University of Muhammadiyah Malang.

Silalahi, U., \& Atif, N. F. (2015). Metode penelitian sosial kuantitatif: Refika Aditama.

Siregar, N. (2018). Hubungan Keyakinan Orang Tua dengan Self-Efficacy Matematis Siswa Kelas IV.

Soendari, T. (2012). Metode Penelitian Deskriptif. Bandung, UPI. Stuss, Magdalena \& Herdan, Agnieszka, 17.

Suardi, M. (2018). Belajar \& pembelajaran: Deepublish.

Suciati, P. I. (2001). Teori belajar dan motivasi. Jakarta PAU-PPAI, Univ. Terbuka.

Sugiyono, S. (2010). Metode penelitian kuantitatif dan kualitatif dan R\&D: Alfabeta Bandung.

Suliyanto, S., \& MM, S. (2017). Metode Penelitian Kuantitatif.

Tan, J. H., Ismanto, A. Y., \& Babakal, A. (2013). Hubungan antara dukungan orang tua dengan motivasi belajar pada anak usia sekolah kelas IV dan V di SD Negeri Kawangkoan Kalawat. Jurnal Keperawatan, 1(1).

Uno, H. B. (2006). Orientasi baru dalam psikologi pembelajaran. Jakarta: Bumi Aksara.

Zahara, F. (2012). Hubungan Dukungan Sosial Orangtua dan Motivasi Belajar dengan Kemandirian Belajar Siswa di SMA Negeri 7 Medan. 